\title{
Malaysian Muslims Lead in Balancing Religious Observance and Social Development
}

\author{
Daud AbdulFattah Batchelor ${ }^{*}$
}

It has always been a big question: Which Muslims in what Muslim country are closer to achieving the ideal of Islamic wellbeing? Whose country is doing better at applying Islamic values? One response is a newly formulated rating index, the Islamic Index of Well-being (IIW), which suggests that Muslims in Malaysia lead the Muslim countries surveyed in Islamic well-being, just ahead of their Indonesian cousins. These two countries were clearly ahead globally in the group of 27 out of the 51 Muslim-majority countries for which full data was available to be assessed. Senegal, the Palestinian territories and Bangladesh came next, followed by other Middle-eastern countries, then the sub-Sahara African countries. Ex-communist bloc Muslim countries have the lowest indices, no doubt a consequence of the severe anti-religious policies formerly applied there, including widespread persecution. The results reflect a relative lag of Middleeastern countries in this index, given that they are traditionally considered as the heart of the Muslim world.

The new rating method follows an objective approach, applying principles derived from Islam's revealed scripture, the Qur'an, and the Sunnah, the example and teachings of Prophet Muhammad (pbuh). This analysis identified two key fields for wellbeing: personal religious observances, or acts of worship (ibadah), and good social interactions ( $m u^{\prime}$ amalah): each is given equal weighting in calculating the index.

Personal religiosity levels were obtained from the results of interviewing 38,000 Muslims throughout the world from 2008 to 2012, as published by the respected Pew Research Center in the United States. Gulf Arab countries and Brunei, the 'oil shaykdoms', did not participate, but it is hoped they could be represented in future surveys. These surveys provide the key information on the percentage of Muslim citizens who perform obligatory (fardu 'ayn) practices of praying five times daily, men attending the mosque at least once weekly for Friday prayers, and Muslims fasting in the month of Ramadan. Extensive published research over the past ten years confirms that those who are more attached to traditional religious practices, among both Muslims and non-Muslims, generally experience higher levels of psychological well-being.

Five fields were assessed for determining social interactions of Muslim countries. These were first, the proportion of citizens having an education at least to secondary school level, then a good status given to women, good care of young children, not too much disparity in family income levels as reflected in the Gini 
index of income inequality, and the elimination of corruption. From an Islamic perspective, governments are required to assist vulnerable members of society, assistance which is reflected in the indicators used to determine the status of women, children and the poor. As this information was freely available from the United Nations and other reputable published sources such as Transparency International (for corruption levels), virtually all Muslim countries could be rated for their achievements in societal well-being. Not surprisingly, United Arab Emirates is first, Brunei second, Kuwait and Oman are both third, performing best in this field, followed by Malaysia and some of the former communist bloc Muslim countries.

The most surprising and perhaps most significant finding of the study is that the West African bloc of countries (Nigeria, Chad, Senegal, Niger, Mali) and Afghanistan that display the highest levels of personal religiosity at the same time demonstrate the lowest levels of the social interaction indicators. This contrast suggests that countries with pious Muslim citizens do not necessarily do well in building their social institutions, such as in public health and education, and in their broader community interactions. Certainly this anomaly deserves followup investigation to clarify the main reasons for the disparity. As an example, in Nigeria, it has been estimated that one million women and children die every year from largely preventable causes. Most of the childhood deaths are due to polio, malaria, measles, bacterial meningitis, and malnutrition. Because these are mostly poorer Muslim countries, lack of financial resources to improve their social welfare condition may be a cause. It is countries such as these that deserve greater support from the wealthy Muslim countries blessed with natural resources.

Muslims from a broad national platform deserve recognition for Malaysia's good standing as reflected in its high Islamic Index of wellbeing. The impressive achievement of Malaysia in the Muslim world was also acknowledged in October last year in a letter to Malaysian Prime Minister Datuk Seri Najib Tun Razak by the eminent scholar, Shaykh Yusuf Al-Qaradawi, who observed that "Malaysia has been distinguished among Muslim countries with its impressive development strategy and openness, evolving as a referential centre and model for the Muslim world." A number of possible reasons for the high level of well-being of Southeast Asian Muslims could be suggested: the relatively soft approach towards Islamisation historically; the substantial role of Muslim women in these societies; the lack of destructive wars in the region; the benefit provided from the Asian "economic miracle" in building strong economies, accompanied by the appropriate allocation of public funds to enhance education, health and social welfare. Also the transformation in Indonesia from military rule to a functioning system of representative governance has benefited the people of the world's largest Muslim country. 
The approach discussed here holds promise in assisting state planning efforts to improve well-being, particularly of the most vulnerable citizens, and to encourage improvements in education, health, and religious practice. It is a broadly applicable analytical tool to help monitor progress, as Muslims move forward into the future, both in the reverential practice of their faith and in attention to their daily affairs in society, within their country of residence.

The new IIW methodology, which was developed at the International Institute of Advanced Islamic Studies (IAIS) in Kuala Lumpur, was published in the Institute's April 2013 Journal of Islam and Civilisational Renewal.

\section{Note}

* Daud AbdulFattah Batchelor, an Australian scholar, is Associate Fellow at IAIS Malaysia. He has a broad experience in industry, academia and international consulting covering the fields of Environmental Management, Islamic Political Science and Earth Sciences. Daud has taught at Sultan Qaboos University, Oman and Universiti Sains Malaysia. He has been active in Muslim community organisations and is co-founder of the Islamic College of Brisbane. Daud has an MA in Islamic and Other Civilisations from ISTAC, and was presented the Longmans Award for PhD research at Universiti Malaya. He has an MSc from the Imperial College of Science and Technology, London and a Master of Engineering Science. Publications comprise 50 articles including: "Flaws of 'Democracy' facilitate dangerous elite control over Australian foreign policy", "The 'Lucky Country' bordering the Malay Muslim world", and the Federation Museums Journal issue covering the Dengkil archaeological site he discovered. He is currently working at assisting the Afghanistan peace process by determining how differences may be resolved to achieve a workable political framework, in the context of his current research focus on Islamic political systems. 